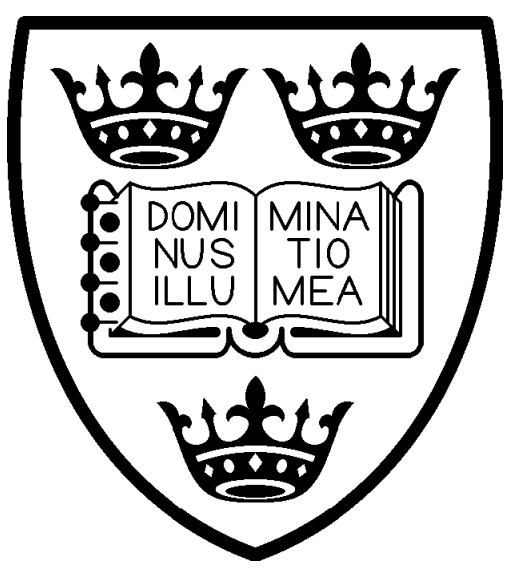

UNIVERSITY OF OXFORD

Discussion Papers in Economic and Social History

Number 150, December 2016

\title{
INDEPENDENT IRELAND IN COMPARATIVE PERSPECTIVE
}

Kevin Hjortshøj O'Rourke 


\title{
Independent Ireland In Comparative Perspective
}

\author{
Kevin Hjortshøj O'Rourke
}

All Souls College, Oxford

\begin{abstract}
This paper surveys independent Ireland's economic policies and performance. It has three main messages. First, the economic history of post-independence Ireland was not particularly unusual. Very often, things that were happening in Ireland were happening elsewhere as well. Second, for a long time we were hampered by an excessive dependence on a poorly performing UK economy. And third, EC membership in 1973, and the Single Market programme of the late 1980s and early 1990s, were absolutely crucial for us. Irish independence and EU membership have complemented each other, rather than being in conflict: each was required to give full effect to the other. Irish independence would not have worked as well for us as it did without the EU; and the EU would not have worked as well for us as it did without political independence.
\end{abstract}

This is a revised version of a lecture delivered on November 11, 2016, at the NUIG National Conference entitled 1916-2016: The Promise and Challenge of National Sovereignty. I am extremely grateful to Nicholas Canny for having invited me; to everyone at NUIG for their hospitality; to John McHale for chairing the session so expertly, and to the discussants for their excellent comments. I am also grateful to Brian Ashcroft, Frank Barry, Jason Begley, George Boyer, Alan de Bromhead, Graham Brownlow, Diane Coyle, Richard Dorsett, Alan Fernihough, James Foreman-Peck, Frank Geary, Stefanie Haller, David Jordan, Aidan Kane, Michael Keating, Morgan Kelly, Dave Madden, Maurice Mulcahy, Cormac Ó Gráda, Eunan O'Halpin, Andy O'Rourke, Martin Sandbu, and Rebecca Stuart, for many helpful comments, advice, data, and technical assistance. The usual disclaimer applies. 


\section{Introduction}

Somebody clever, I'm not sure who, is supposed to have once said that "he who only tries to understand Ireland will not even understand Ireland". There can at times be an attentionseeking particularism about Irish writing- look at us, we like to say, mostly to ourselves, but if possible to any foreigners who might be listening as well - look at us, and at how unique, and at how very interesting we are.

When I was a young boy in primary school, we were taught that post-independence Ireland was poor but uniquely virtuous. Today, we are taught that it was poor and uniquely wicked. Both positions are misguided: we were never as different as people have made out. Those traditional rural values that we once correctly celebrated can still be found in agricultural communities around the world; meitheal is not a uniquely Irish phenomenon. And the Magdalene Laundries that we now correctly condemn have their counterparts elsewhere as well. ${ }^{1}$ The past, it turns out, is a foreign country everywhere.

And what is true of Irish social history turns out to be true of Irish economic history as well. Very often, the things that were happening in Ireland at a particular time were in fact part of a bigger, European, or even global story.

I used to think that the quotation with which I started this lecture was due to Nicholas Canny, whose own work has largely been concerned with placing the history of early modern Ireland into the context of the wider world - but he denies it.

On the other hand, I am quite certain that it was Rudyard Kipling who once asked "what do they know of England who only England know?" It seems as though the temptation to focus on one's own country, and to ignore what was going on around it, is not just an Irish phenomenon - which of course merely reinforces the point that we are not as unique as we sometimes think we are.

\footnotetext{
${ }^{1}$ On Denmark, see Adler-Olsen (2014).
} 
My main purpose in this lecture is therefore to place Ireland's post-independence economic history into some sort of comparative context, and to try to convince you that in fact our economic history is in many respects not all that unusual.

The circumstances of our state's birth were of course dramatic, and for a while we held the world's attention; but then we settled down to become what we had chosen to become: a small, rather poor country on the periphery of Europe. In many ways, I'm going to argue, our subsequent economic history is precisely what you would have predicted, given the turn that $20^{\text {th }}$ century European history was about to take. Our economic policies were not that unusual in the context of the time; and over the long run our economic performance was just about exactly what you would have predicted as well.

But this conference is of course taking place under the shadow of Brexit, and the question which arises is: will Boris and his merry band of Brexiteers succeed in finishing the job which was begun in 1916, and complete the economic and political separation between our island and Great Britain? Will their efforts lead to Ireland becoming more fully independent of Britain than it has been to date, and perhaps uncomfortably so? Will we have to stand more squarely on our own two feet than we might perhaps want?

And so a second major theme in my talk will be Ireland's economic relationships over the course of the last century with both Britain and continental Europe. If there is one way in which our post-independence economic history was indeed unusual for many decades, and unhelpfully so, it was our excessive dependence on a poorly performing British economy. Membership of the European Communities in 1973, and the European single market programme of the late 1980s and early 1990s, were absolutely crucial in transforming Irish fortunes.

\section{The $19^{\text {th }}$ century back story}

It doesn't make sense to discuss Ireland's post-independence economic performance without spending at least some time on the colonial back story. Irish economic performance under British rule was disappointing, and occasionally tragic. The Famine of the 1840s was 
genuinely unusual - the last mass subsistence crisis in peacetime Western Europe, with the exception of the Finnish famine of the 1860s. As we all know, it ushered in a wave of mass emigration which persisted into the $20^{\text {th }}$ century, and which led to the quite unique spectacle of a continuously declining population throughout the late $19^{\text {th }}$ century, a time when Europe as a whole was experiencing a population explosion.

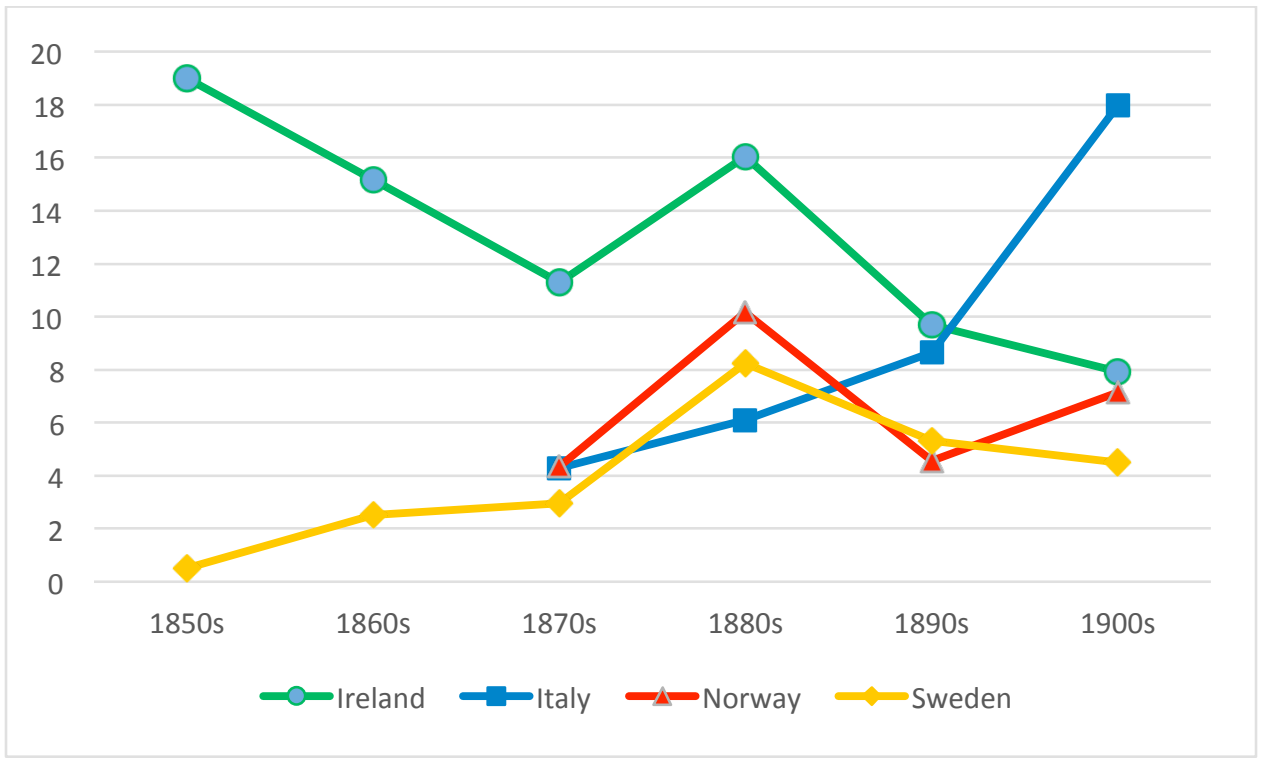

Figure 1. Gross decadal emigration rates, per 1000

Source: Hatton and Williamson (1994, p. 536).

Even here, however, we have to be careful not to overdo the peculiarity of the Irish experience. By the end of the period, Italy was experiencing emigration rates well in excess of our own, with Norway also experiencing heavy outflows (Figure 1). Furthermore, the same underlying forces were driving emigration throughout Europe during this period. Emigration rates were systematically higher in: countries with higher birth rates; countries that were poorer; and countries with a prior history of emigration (Hatton and Williamson, 1998). Ireland's marital fertility rate was high; the country was very poor; and the famine had resulted in an extremely high stock of Irish people living overseas, and particularly in North America. High emigration rates are exactly what you would have expected in the circumstances; there is no need to appeal to any supposed peculiarities of the Irish psyche in order to explain our high propensity to leave the country during the period. ${ }^{2}$

\footnotetext{
${ }^{2}$ Guinnane (1997) provides an excellent discussion of $19^{\text {th }}$ century Irish demography.
} 
This $19^{\text {th }}$ century economic history had important consequences for the $20^{\text {th }}$ century. I want to highlight three legacies in particular.

First: Since a history of previous emigration leads to a higher tendency to emigrate in the future, Irish people remained extremely mobile after independence. Indeed, the population of the 26 counties continued to decline until 1961. Emigration could be both beneficial and harmful to the economy, in ways that generations of Irish economists, politicians and historians have discussed over the years.

One consequence was that by lowering the domestic supply of labour, Irish emigration raised Irish wages, pulling them up towards the levels available on labour markets overseas. Something very similar happened in both Norway and Italy (O'Rourke and Williamson, 1999, Chapter 8). On the one hand, this helped sustain living standards that would otherwise not have been attainable; but on the other, it deprived the economy to at least some extent of one of the main advantages which poor countries generally possess, namely cheap labour.

On the eve of World War I, Ireland was still poor, but it was clearly much richer than it had been in the 1870s, let alone the 1840s. But growth in per capita living standards that was largely due to a declining population was hardly anything to shout about. Southern Ireland's prosperity in 1913, such as it was, was based on very different foundations than prosperity elsewhere. The key to economic growth during the late $19^{\text {th }}$ century was typically industrialisation. And the key to industrialisation, in Germany, Italy, France, the United States, and elsewhere, was protectionism.

During the late $20^{\text {th }}$ and early $21^{\text {st }}$ centuries, globalisation and growth have gone hand in hand, but tariffs protecting industry were strongly and positively correlated with growth before the First World War (Lehmann and O'Rourke, 2010). As a region of the free trading United Kingdom, an independent tariff policy was obviously unavailable to Ireland. The data plotted in Figure 2 show that nationalists were not mad, in the context of the time, to believe that this was a serious handicap. And so a second legacy of the $19^{\text {th }}$ century, which became important in the $20^{\text {th }}$, was an ideological commitment to protectionism among a certain stratum of Irish nationalist thinkers. Once again, there was nothing unusual about 
this; it was rather the United Kingdom, with its strong commitment to more or less unilateral free-trade even as its rivals gained market share at its expense, which was the exception during this period.

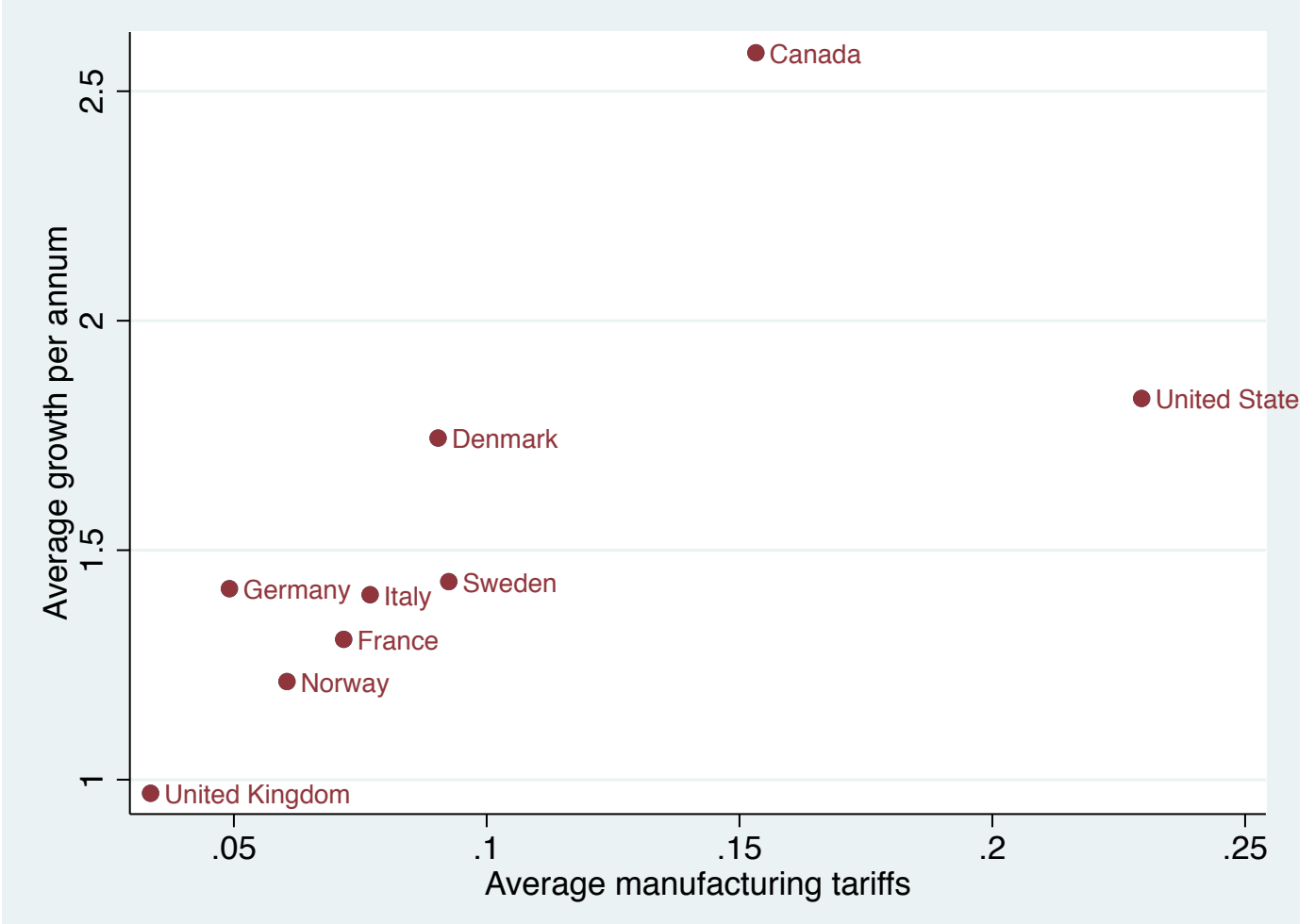

Figure 2. Manufacturing tariffs versus growth, 1875-1913

Source: based on data in Lehmann and O'Rourke (2010).

But this intellectual commitment to protectionism would eventually run up against a third legacy of Ireland's history, which was the extent to which the Irish and British economies were intertwined. The south of Ireland was overwhelmingly specialised in agricultural activities, and its agricultural exports went overwhelmingly to the United Kingdom. The Irish and British labour markets were very tightly integrated with each other. The Irish Free State, and later the Irish Republic, would share a common legal system with Britain, as well as a common currency, and many other institutions. For much of the $20^{\text {th }}$ century it makes sense to regard Ireland as one small regional component of a broader British and Irish economy. And the problem was that this broader British and Irish economy, within which the British component was obviously overwhelmingly dominant, was a poor performer within the broader European context. Only when we emancipated ourselves from excessive reliance on 
our nearest neighbour were we able to finally grow as rapidly as other poor countries around the European periphery.

\section{Assessing Irish performance}

In order to assess Ireland's economic performance, we need a benchmark. ${ }^{3}$ Because of our history, a natural tendency is to use the UK, but that is an important mistake. The UK performed poorly relative to most European economies: by using it as a benchmark, we are setting the bar much too low.

A second alternative is to compare Ireland with similar regions inside the UK - Northern Ireland most obviously, but perhaps also Scotland and Wales. As we will see, doing so provides us with several useful insights, but again, by comparing ourselves with regions located within the slowly growing UK economy, we are setting the bar too low.

A third alternative, which makes a lot more sense, is to compare ourselves with other relatively poor economies around the European periphery. Greece, Portugal and Spain were all as poor as Ireland at the start of the $20^{\text {th }}$ century, if not poorer. They therefore faced many of the same obstacles that we did, but they also shared the same potential for rapid growth based on catching up on the industrial core. How did we do compared with these economies? Indeed, how did we do compared with European economies more generally?

\footnotetext{
${ }^{3}$ For a similar discussion, see Ó Gráda (1997, pp. 2-4).
} 


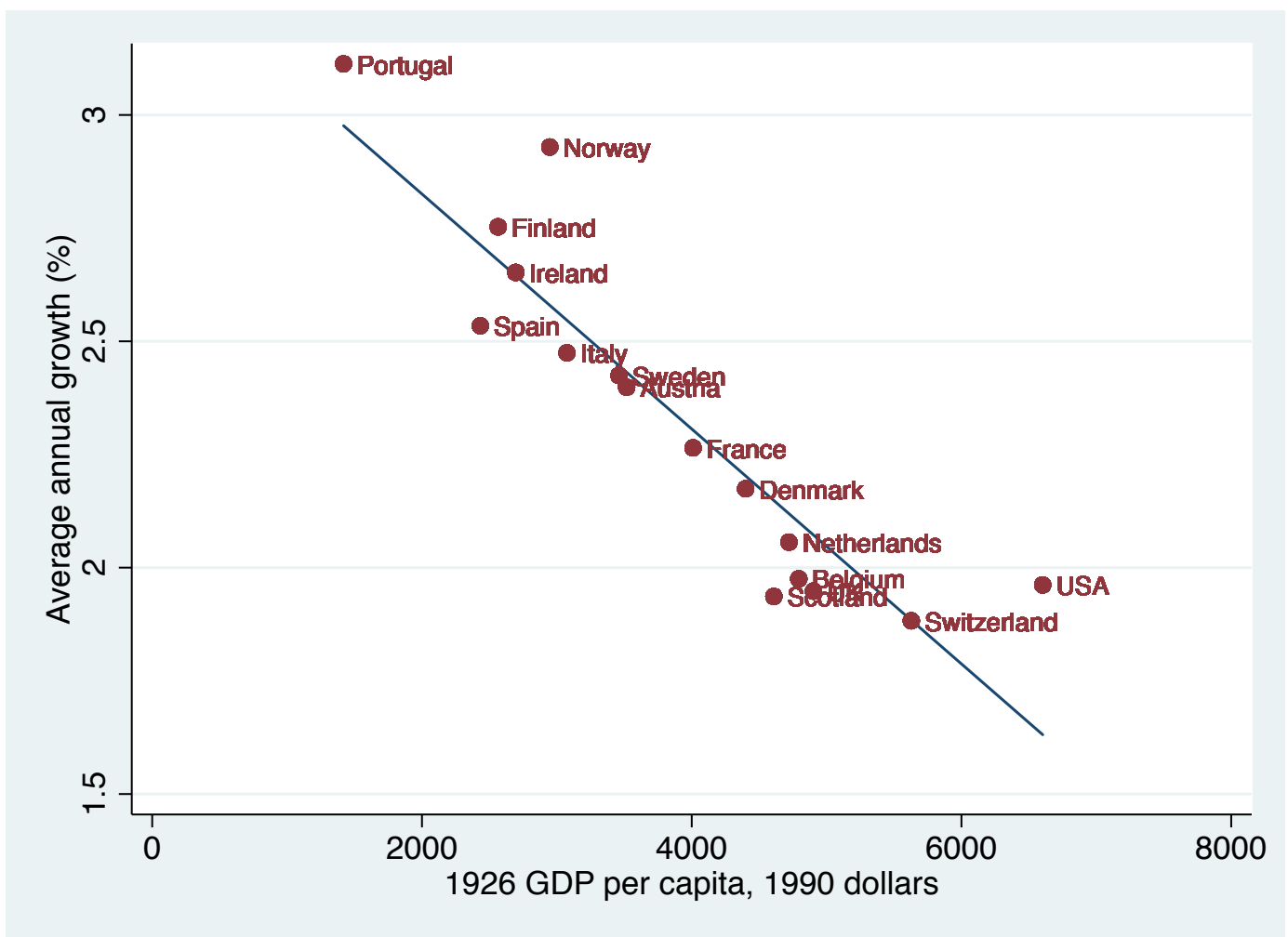

Figure 3. Initial income and subsequent growth, 1926-2001

Source: Broadberry and Klein (2012). GNP rather than GDP is used for Ireland, using adjustment ratios kindly provided by Rebecca Stuart. Her data go back to 1944 so I have simply assumed that GNP was the same proportion of GDP in previous years.

It is a matter of statistical fact that within Western Europe, countries that were initially poorer have grown more rapidly than countries that were initially richer during the $20^{\text {th }}$ century. In other words, poorer economies have tended to converge on richer ones, mostly as a result of importing best practice technologies already adopted elsewhere. We don't have reliable national income evidence for Ireland before 1926, so Figure 3 plots initial income levels, per capita, in 1926, against average growth per annum over the course of the subsequent 75 years. I have done this for the broadest available sample of European countries that managed to avoid becoming Communist later in the century, as well as the United States. As can be seen, there is a very clear negative relationship between these two variables. Initially poor countries, such as Portugal, grew much more rapidly than initially rich countries such as Switzerland. The average statistical relationship between these two variables (what economists call "the regression line") is given by the straight line in the figure. As can be seen, the "statistical fit" of this relationship is remarkably tight, in that countries are very closely clustered around this line. 
Strikingly, Ireland's economic performance during the 75 years following 1926 was exactly what it should have been, given Ireland's initial income level. There was nothing unusual about Irish growth during this period. It was an entirely typical European economy.

\section{The interwar period and World War II: 1922-1950}

If there is one thing that is unusual about Irish economic policy-making after independence, it is that it took so long for the Irish Free State to move in a protectionist direction. The successor states of the Austro-Hungarian Empire, for example, immediately implemented a wide range of protectionist measures. By contrast, during the first 10 years of Irish independence our trade policy was, comparatively speaking, remarkably liberal.

As we all know, the election of Fianna Fáil in 1932 coincided with a dramatic shift towards protection. But there are three questions about this policy shift that we can usefully ask. First: are its causes really to be found in Irish party politics alone? Second, was Ireland unusually protectionist? And third, was Irish protectionism unusually costly?

Regarding the first question: it would be a mistake to view the switch to protection as having had causes that were fundamentally idiosyncratic and Irish. Everybody switched towards protection following the onset of the Great Depression in 1929. Even the traditionally free-trading British moved decisively towards protection in November 1931 and February 1932 - that is to say, before Ireland.

This common trend requires a common explanation, which is provided by the Great Depression. The Great Depression arose from a catastrophic macroeconomic policy failure, largely associated with the gold standard of the period. This ruled out the sorts of loose money policies that have been used in many economies during our own Great Recession, and was associated with an extremely conservative mindset when it came to fiscal policy as well. Governments thus found themselves unable to combat falling output and rising unemployment using the sorts of measures that Keynes was advocating at the time; with their hands thus tied behind their backs, they resorted to the only policy lever available to 
them, namely protection (Eichengreen and Irwin, 2010). The hope was that this would create domestic jobs by shielding the local economy from import competition, and in fact in many cases, including our own, it did so. On average, higher tariffs were associated with better economic performance during the interwar period, other things being equal (Clemens and Williamson, 2004). From a collective point of view of course, it would have been far preferable for everyone to have adopted coordinated and expansionary macroeconomic policies, as was done in 2009 , and for them to have maintained relatively free international trading conditions. But this is not what happened, and it would be wrong to single out Ireland for special criticism in this regard.

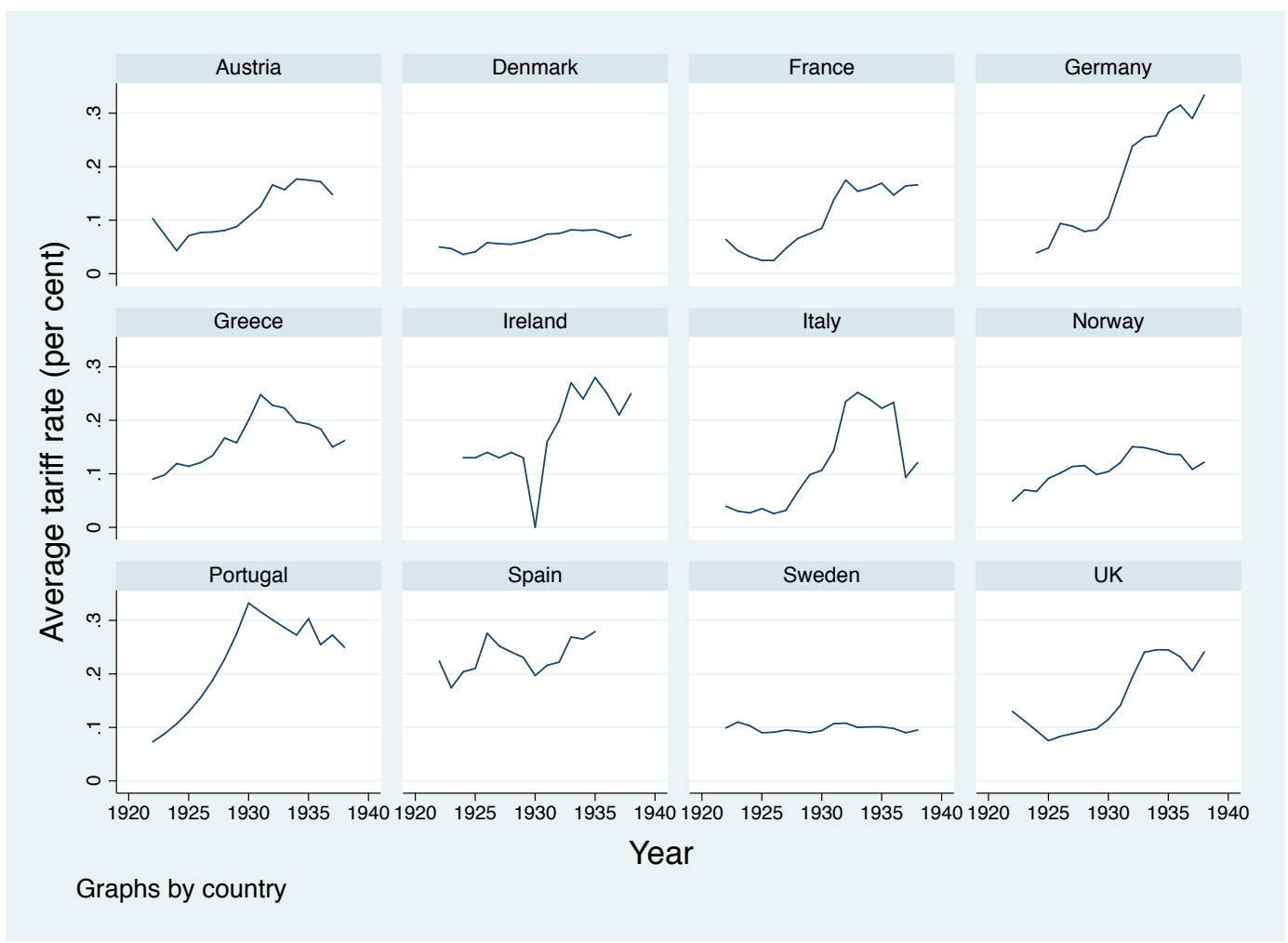

Figure 4. Was Ireland unusually protectionist? Average tariffs 1922-38

Source: Clemens and Williamson (2004) and www.duanaire.ie at NUI Galway.

Was Ireland unusually protectionist during the 1930s? The answer is no. Irish average tariffs were towards the higher end of the spectrum in the sample of European countries for which we have data, but they were similar to those in Germany, Italy, Portugal, Spain, and the UK (Figure 4). But focusing on tariffs alone is misleading, since these were not the real problem during the 1930s. Rather, countries during this period adopted a wide variety of quantitative restrictions on trade, up to and including exchange controls which in some cases effectively 
nationalised the international trading activities of particular countries. Ireland didn't do anything nearly as drastic. And as can be seen from Figure 5, it was towards the more liberal end of the spectrum when it came to the adoption of quotas as well.

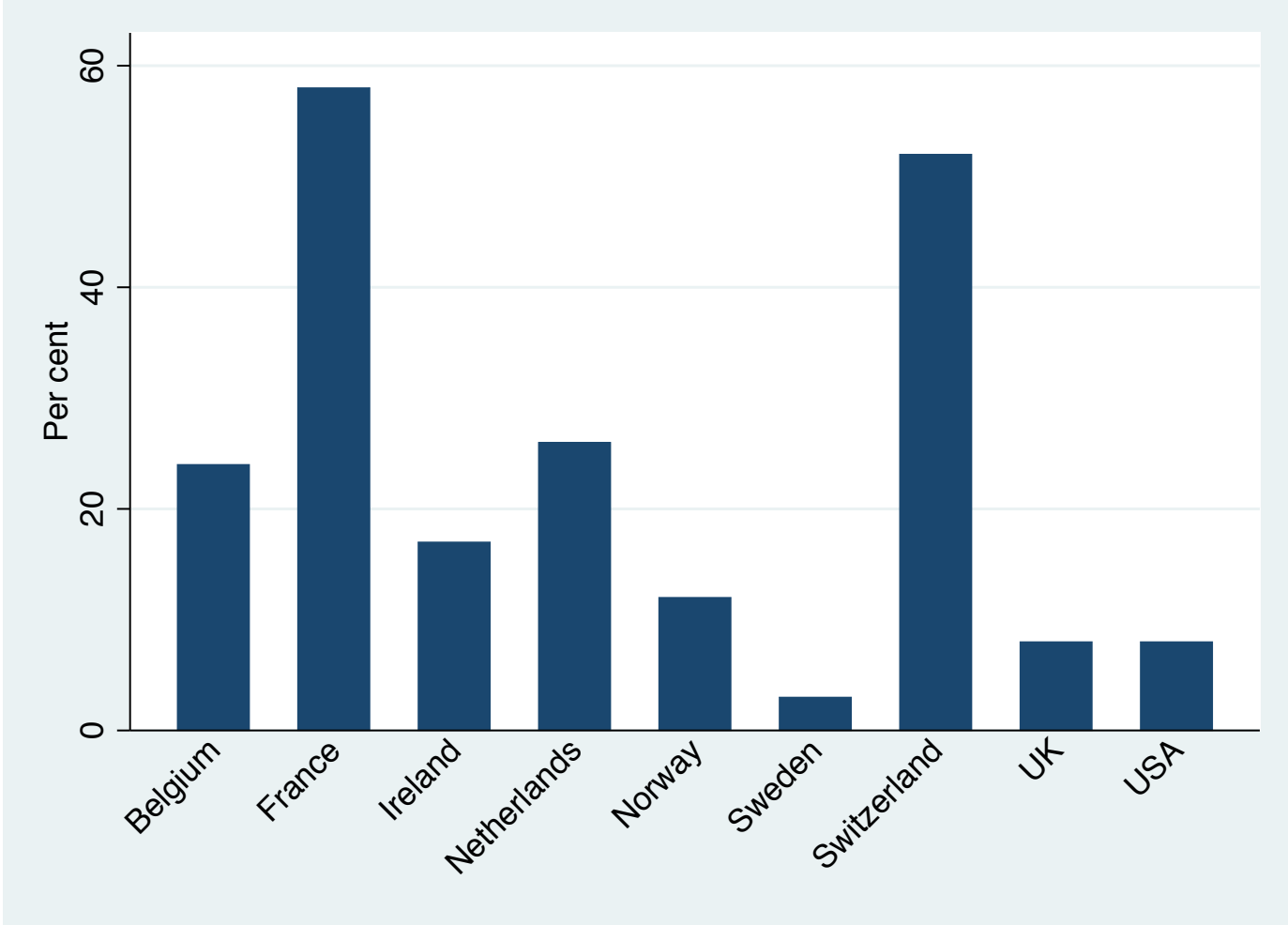

Figure 5. How unusual was Irish trade policy? Percentage of imports covered by quantitative restrictions, 1937

Source: League of Nations (1943), Whittlesey (1937).

Another well-known feature of Irish economic policy during this period was its attempts to restrict the foreign ownership of Irish-based firms. But the importance and uniqueness of the 1932 and 1934 Control of Manufacturers Acts can be overdone. First, as work by Mary Daly, Frank Barry and others has revealed, these formal restrictions were often evaded by means of fancy legal footwork, as indeed was the case in other countries during this period (Daly, 1984; Daly, 1992; Barry et al., 2016). ${ }^{4}$ Second, Ireland was by no means alone in

\footnotetext{
${ }^{4}$ For example, the Italian tyre company Pirelli registered its foreign-owned operations as belonging to a legal entity based first in Belgium, and later in Switzerland, which would prove convenient when doing business with the Allies during World War II. Cf. Jones (2013, pp. 197-8).
} 
adopting such restrictions. Spain restricted the foreign ownership and management of all firms to a maximum of 25\% in 1939 (Lieberman, 2006, p. 131). In the same year, Finland tightened its existing restrictions on inward foreign investment, prohibiting the acquisition of real estate by foreign individuals, organisations, and Finnish companies which did not restrict foreign ownership to a maximum of $20 \%$ of the outstanding shares (Hjerppe, 2004, pp. 4-5). Portugal restricted inward investment in 1943 (das Neves, 1996, p. 331). Other examples could be found.

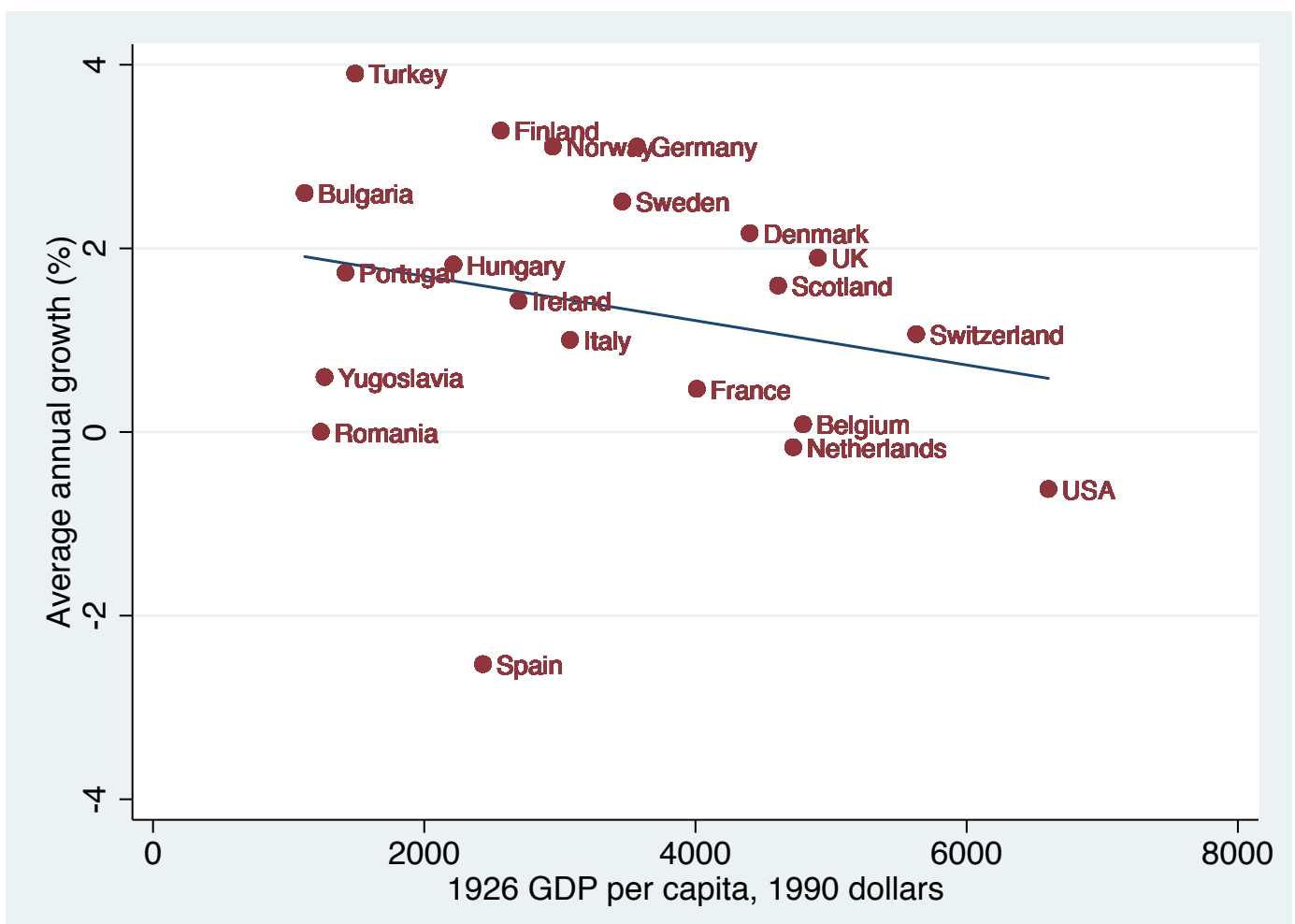

Figure 6. Initial income and subsequent growth, 1926-1938

Source: as for Figure 3.

Were the economic effects of protectionism uniquely destructive in Ireland? Again, the answer is no. As Figure 6 shows, not only were Ireland's economic policies typical during this period, so was its economic performance. Between 1926 and 1938, Ireland grew at exactly the rate that it should have done, given its initial starting point. 
Importantly, protectionism probably helped maintain employment at a time when jobs were scarce everywhere. It is true that the economic war with Britain, which lasted from 1932 to 1938 , was somewhat unusual - although Ireland was hardly alone in defaulting on its debts during this period. But it is also true that the dispute was settled on terms highly favourable to the Irish. A capitalised $£ 100$ million liability was settled with a $£ 10$ million lump sum payment, and Ireland gained the Treaty Ports into the bargain. This surely helped the country to remain neutral during World War II. Neutrality certainly saved many Irish lives, and it is entirely possible that it avoided much destruction to Irish property. Even taking the undoubted costs of the Economic War into account, it is entirely plausible that its net economic impact was actually beneficial (Neary and Ó Gráda, 1991; O'Rourke, 1991).

The war itself was a very difficult period for the Irish economy, even though we were spared the horrors of the fighting. Imports of energy and other essential requirements were very scarce; domestic industry suffered accordingly. As a predominantly agricultural economy, with no heavy industry to speak of, the Irish Free State did not benefit from the demand for war-related matériel in the way that Scotland or Northern Ireland did. Even worse, it found itself selling its agricultural output to a hard-pressed British customer, which quite understandably used its monopoly position to lower the prices it paid for Irish agricultural produce. Even still, Irish farmers were the only section of the community to see their living standards rise between 1939 and 1943 (Ó Gráda, 1997, pp. 7-21).

In common with almost all of Western Europe, Ireland experienced a strong boom between 1945 and 1950. In formerly belligerent powers, especially on the continent, the boom largely took the form of reconstruction. In the Irish case, it was far more consumptiondriven, as consumers made up for lost time and bought American and other imported goods. Construction also boomed, as did industry (ibid., pp. 21-25). Such a consumptiondriven boom was probably less sustainable than the more investment-based booms experienced in continental Europe at the time. Nevertheless, the overall impression that one gets when placing Irish economic policies between 1922 and 1950 into a comparative perspective is that there was nothing unusually perverse or self-destructive about Irish policy choices during this period. Irish politicians were relatively liberal during the 1920s, and were protectionist like everybody else from 1932 onwards. They were hardly to blame 
for the deprivations of World War II, nor could they be praised for the inevitable recovery which followed. And the country's economic performance during the first 30 years of independence was also pretty typical for the time.

\section{Ireland falls behind: $1950-1973$}
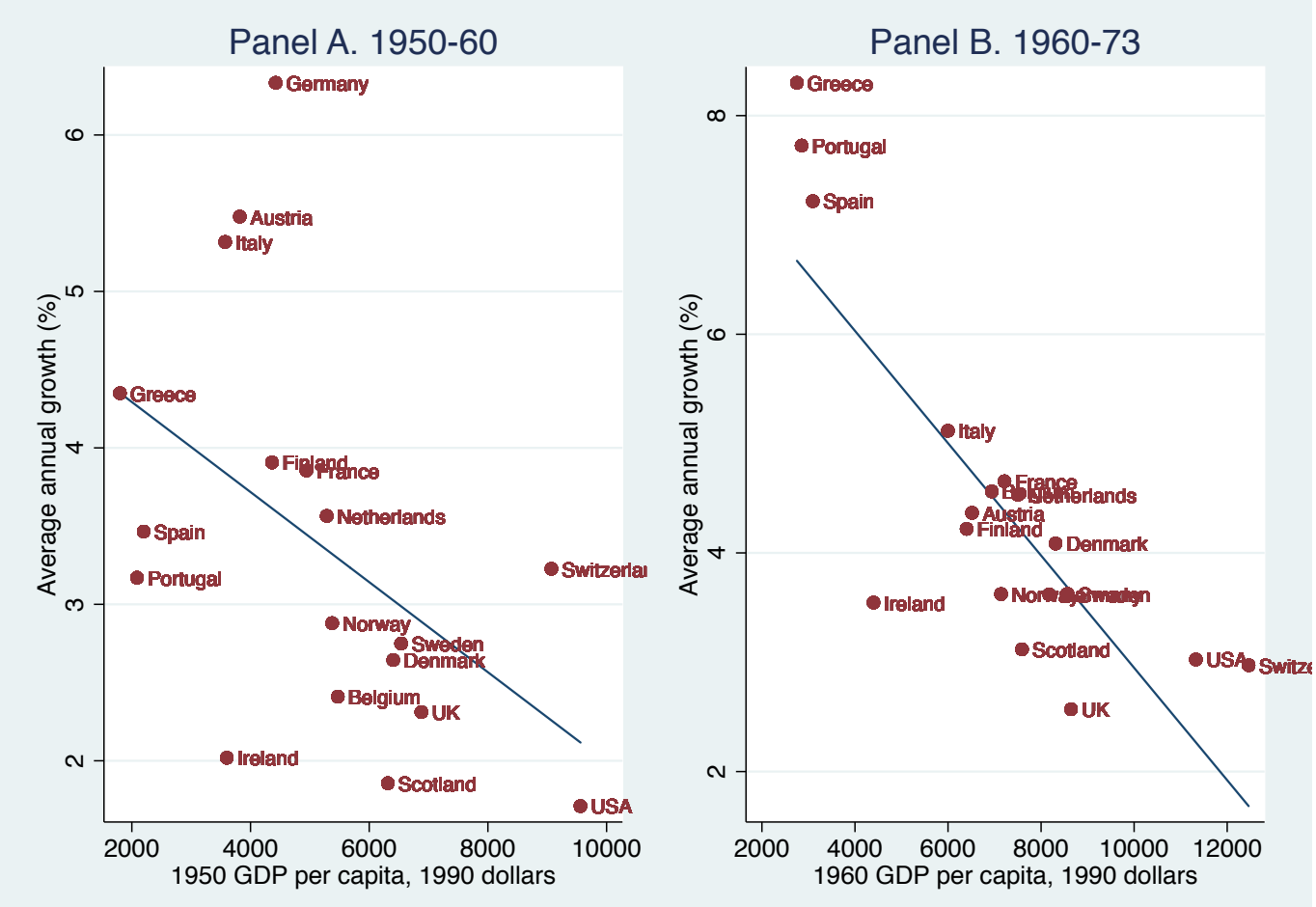

Figure 7. Initial income and subsequent growth, 1950-60 \& 1960-73

Source: as for Figure 3.

In contrast, Ireland's performance during the subsequent 25 years was disappointing. Whereas Ireland had been an average performer during the dismal interwar period, it performed well below average during Europe's "Golden Age". The 1950s were as we all know particularly bad, and the GNP data plotted for Ireland in Panel A of Figure 7 understate the case, if it is the living standards of ordinary people that we are concerned with. Throughout post-war Europe, governments erected modern welfare states, but Ireland lagged far behind. If independent Ireland can be said to have "failed" during any period, it did so most obviously during this decade. 
What may come as more of a surprise is the fact that Irish underperformance continued during the 1960s. As can be seen from Panel B of Figure 7, this was the decade during which Greece, Portugal, and Spain experienced their economic miracles. Ireland, by contrast, was still an underperformer. Importantly, a comparison with Britain alone would miss this: from 1960 onwards the Irish economy grew more rapidly than the British one. But growing more rapidly than an economy which was itself an underperformer was not enough to prevent Ireland from falling even further behind mainstream Europe.

Why was Ireland's performance so poor during these two crucial decades? I want to highlight three reasons. The first has to do with recurrent balance of payments crises; the second has to do with delayed liberalisation; and the third has to do with our excessive dependence on the poorly performing British economy.

The first feature of the Irish economy during the 1950s and early 1960s which was obvious to people at the time, but is less often commented upon today, was the succession of booms and busts. ${ }^{5}$ The post-war boom ended as a result of a balance of payments crisis which emerged in 1950, and got worse in 1951. This ultimately led to the highly deflationary budget of April 1952, which caused a deep recession. By 1955 the economy was recovering, consumption was booming, and imports were rising rapidly. Once again, the eventual response was not one, but two austerity budgets in 1956, leading to a deep recession lasting several years. 10 years later, a rising trade deficit in 1965 was followed by yet another deflationary budget in 1966. This succession of booms and busts was highly destructive. It also poses the question of whether Irish policymakers were uniquely incompetent.

As it happens, they were not. This sequence of loosening fiscal policy, leading to rising incomes, rising imports, balance of payments crises, and thence to tightening fiscal policy, falling incomes, falling imports, and improvements in the balance of payments, was wellknown in the United Kingdom and other countries at this time. The UK, for example experienced major crises in 1957, 1961, and 1966. The term that we use to describe this sequence of events is "stop-go policies", and the fundamental reasons for such policies

\footnotetext{
${ }^{5}$ Ó Gráda (1997) is one notable exception, and I draw extensively on him in the account below.
} 
were analysed by an Australian economist, Trevor Swan, in a famous and influential contribution to the macroeconomic literature. ${ }^{6}$ The essential problem, Swan pointed out, was that governments of the time were trying to hit two targets simultaneously, a full employment target and a trade balance target. To hit two targets, you need at least two policy instruments; the problem was that during this period policymakers only had one, namely fiscal policy. The post-war Bretton Woods system was based on fixed exchange rates. These were supposed to be adjustable, and indeed they were occasionally adjusted, but to devalue your currency was seen as failure by politicians, and generally only happened under duress, in the context of major crises such as the one in 1967 which forced Harold Wilson to devalue the British, and thus the Irish, pound.

This implied a major dilemma for countries whose currencies were overvalued. Since their goods were overpriced on international markets, they faced persistent balance of trade problems. These could be overcome by tightening fiscal policy, which would lower expenditure and hence imports, but that came at the cost of higher unemployment. When unemployment became too burdensome, fiscal policy could be loosened again, but this would imply rising trade deficits. The ultimate solution was to devalue the currency; until this happened, stop-go policies would be inevitable. And whereas devaluation was an option for the United Kingdom, it was not something that Irish policymakers could do unilaterally - so long as they were unwilling to break the Irish currency's link with sterling. Until then, booms and busts related to balance of payments crises were unsurprising - and indeed, British and Irish booms and busts were highly correlated with each other during this period. $^{7}$

A second explanation for poor Irish performance during the European Golden Age, and particularly during the 1950s, is the delay in reversing interwar protectionist policies. I have argued that these policies were appropriate in the context of the 1930s, a time when everyone was protecting their domestic markets; when an export-oriented growth strategy was therefore not feasible; and when jobs were scarce everywhere. But by the 1950s

\footnotetext{
${ }^{6}$ Arndt (1976) provides a detailed account of the genesis of the idea.

${ }^{7}$ The correlation between business cycles in the two countries from 1950 to 1972 inclusive is 0.74 , where the business cycle series are simply calculated as deviations from log trend.
} 
protectionism was clearly no longer appropriate. At the urgent behest of the United States, European countries were gradually removing barriers to trade and integrating their economies with each other - first within the context of the OEEC, the forerunner of today's OECD, and later within the context of the EEC and EFTA. This meant that export-oriented growth strategies could now be, and were in fact, adopted throughout Western Europe, while the rapid growth of the period implied that protection was not needed in order to create jobs. There is no doubt that Ireland was slower to jump on the liberalisation bandwagon than many other countries, and that this was a costly mistake.

However, the traditional picture of an Ireland that was completely resistant to change before 1958 is over-simplistic. Ireland was a founder member of the OEEC and European Payments Union, the two organizations at the forefront of European trade liberalization during the early 1950s. When it came to quantitative barriers to trade such as quotas, which are more damaging than tariffs, Ireland was the second least protectionist economy in the OEEC in 1950, behind only Switzerland (Eichengreen, 1996, p. 59). It subsequently liberalized less rapidly than did other countries, but this was partly because it had less quota-related liberalization to do in the first place. Overall, Ireland emerges as an entirely average European country on this dimension of trade policy. It was however slower to lower its tariff barriers than core European economies. It behaved, rather, like other peripheral European economies, such as Finland, Greece, or Spain, and this relatively slow reduction in tariffs persisted into the 1960s, after the famous 1958 move towards greater openness (Figure 8). 


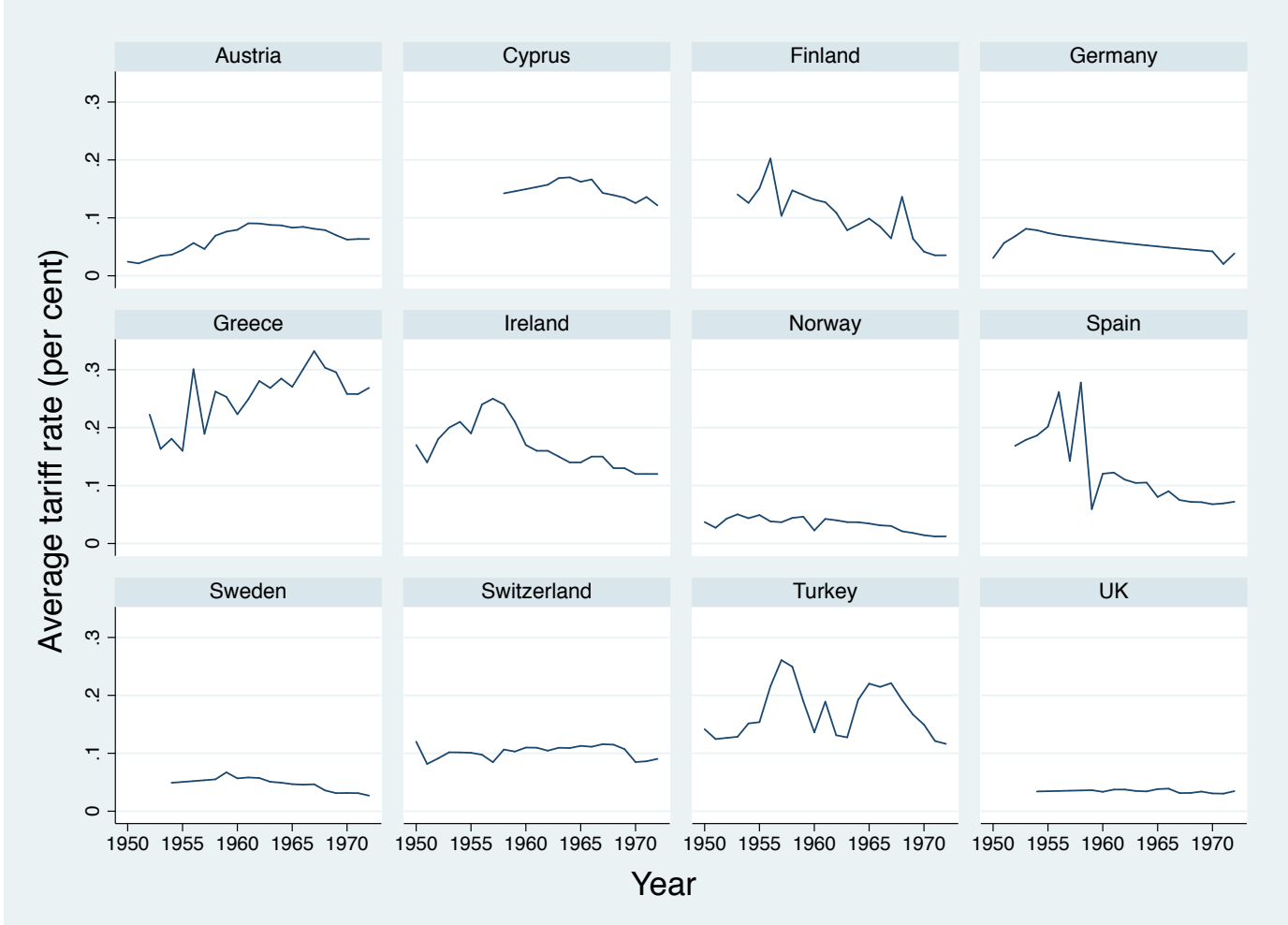

Figure 8. Was Ireland unusually protectionist? Average tariffs 1950-72

Source: as for Figure 4.

On the other hand, Ireland was relatively precocious in seeking to attract foreign direct investment. The Industrial Development Authority was established as early as 1949 , and soon started trying to attract inward multinational investment. The Irish Export Board, soon rechristened Córas Tráchtala, was established in 1950. Tax relief on export profits was introduced in $1956 .^{8}$

Ireland was therefore not as uniquely protectionist and inward -looking during the 1950 s as is sometimes claimed. Neither was the timing of its liberalisation particularly unusual. It is true that the original six members of the EEC had begun their move towards greater

\footnotetext{
${ }^{8}$ In light of recent controversies it is interesting to note that this soon appeared as a potential concern on the radar screens of foreign governments, appearing to be potentially in breach of the OEEC ban on artificial aids to exporters. The OEEC approved the initiative however, since it seemed to signal a growing outward orientation on the part of the Irish government (Barry and O'Mahony, 2016).
} 
economic integration as early as 1950, with the foundation of the European Coal and Steel Community. They agreed in 1955 to draw up plans for a customs union, and the Treaty of Rome was signed in 1957.

But the timing of liberalisation elsewhere to a large extent reflected the impact of this initiative on other countries, and notably on the United Kingdom. The UK first tried to sabotage the EEC negotiations. When this failed, they attempted to negotiate an OEEC-wide industrial free trade area, but completely misjudged the interests of other European countries. When this attempt also failed, therefore, the British and six other countries signed the Stockholm Convention in 1960, establishing the European Free Trade Area. This aimed to establish an industrial free trade area between its member states, and ultimately to negotiate an agreement with the EEC as well. No Western European country, no matter how peripheral or economically backward, could avoid responding to this disruption of the prevailing European trade regime.

Spain abandoned its long-standing autarkic trade policy regime in 1959, joining the OEEC in that year and embarking on a process of trade liberalisation. In 1960 it abolished quantitative restrictions on $90 \%$ of its imports, tariffs were gradually reduced over the succeeding years, and the country opened itself up, at least to some extent, to inward foreign investment (de la Escosura and Sanz, 1996, pp. 369-70). Portugal became a founder member of the EFTA, although it managed to negotiate a transitional deal allowing it to delay tariff reductions on sectors representing about half of its imports (Costa et al., 2016, pp. 308-9). Finland started lowering tariffs from 1957 onwards, and signed a trade agreement with the EFTA in 1961 (Paavonen, 2004). Greece signed an Association Agreement with the EEC in 1961. This granted it a 22-year transitional period leading to eventual full membership; Greece was allowed to lower its tariffs vis à vis the EEC gradually, but benefited from an immediate reduction of EEC tariffs on Greek exports (Freris, 1986, pp. 201-2).

And so it is no surprise that Ireland also took the plunge, at more or less exactly the same time, and applied for EEC membership in 1961 along with Britain. Nor is it surprising that when that bid was vetoed by Charles de Gaulle in 1963 - something for which Irish policy 
makers can hardly be blamed -- Ireland unilaterally cut its tariffs. It did so again in the following year, and in 1965 signed the Anglo Irish Free-Trade Agreement. At this stage Ireland was fully committed to eventual EEC membership, which was finally achieved in 1973.

What was unusual about Irish trade liberalisation was the extent to which it remained focused on the economic relationship with Britain. To be sure, the AIFTA was seen as a stepping stone towards eventual EEC membership, but despite this European motivation, the reality was that Ireland was not yet well integrated with the European economy as a whole. And this was a problem, since access to the British market alone was a far less appealing carrot to dangle in front of potential multinational investors than access to the much larger and more dynamic EEC market.

This leads us to the third explanation for Ireland's relatively poor performance during Europe's Golden Age. If the poor performance in the 1950s was due to protectionism, and if, as the conventional wisdom has it, Ireland liberalised in a rush from 1958 onwards, then why was its performance so disappointing between 1960 and 1973? The comparison with other peripheral European economies, in particular Greece and Portugal, is illuminating. As we have seen in Figure 7, Greece and Portugal grew extremely rapidly during this period, while Ireland remained an underperformer. And as we have also seen, in Figure 8, Greek tariffs were even higher than Irish ones during the 1960s. What can explain the superior performances of Greece and Portugal? Why did Ireland not keep pace?

A key factor in the Greek success story was the country's Association agreement with the EEC. Foreign investment had been encouraged since the early 1950s, when a series of FDIfriendly policies were introduced (Freris, 1986, pp. 171-2), but tariff-free access to EEC markets provided an essential additional stimulus to inward investment. Between 1962 and 1964, more than three fifths of all manufacturing investment was foreign; Kopsidis and Ivanov (2017, p. 108) argue that FDI during this period "diversified and modernised Greek industry". Continent-wide markets for cheap consumer goods produced in Greece also benefited traditional Greek light industry. 
In Portugal too, EFTA membership is seen as having been crucial in promoting a more outward-looking and dynamic economy. According to one estimate, annual inflows of foreign direct investment were more than 30 times higher during the 1960s than they had been between 1943 and 1960 (Ferreira da Silva, 2016). ${ }^{9}$ Portuguese accession to the EEC in the 1980s would lead to a further step increase in inward foreign investment, as happened also in Spain (Barry and Bradley, 1997, p. 1809).

A key difference, therefore, between the Irish case, on the one hand, and the Portuguese and Greek cases on the other, was that Ireland had neither an Association agreement with the EEC, nor membership of the EFTA. ${ }^{10}$ We tend to assume that once Ireland had signed the AIFTA, it was to all intents and purposes a free trader, and there is something to this. Local firms had to adjust to British competition, and this was good for efficiency. But there is a big difference between accepting free trade between oneself and just one country, and becoming part of a continent-wide customs union. Until EEC accession, the IDA had to try to sell Ireland as an export platform into the UK and Commonwealth, but this was never as effective a sales pitch as the one which we were able to make after 1973. From then on, Ireland was selling into the EEC as a whole, and that made all the difference.

One very striking feature of the data between $1954^{11}$ and 1973 is that Ireland's growth performance was very similar to the growth performances of both Northern Ireland and Wales. All three economies seem to be underperforming in a very similar way, growing less rapidly than they should have been given their initial income levels (Figure 9). This suggests that all three economies were facing a common problem or set of problems. Some of these may have been institutional in nature, such as a fragmented trade union structure which made the corporatist arrangements then in vogue on the Continent difficult to achieve (Ó Gráda and O'Rourke, 1996). But an excessive reliance on the sluggish British economy is another plausible candidate.

\footnotetext{
${ }^{9}$ According to the same author, the inflow in 1961 was as high as the total inflow experienced during the entire 1950s. das Neves (1996), on the other hand, downplays the role of FDI during the 1960s.

${ }^{10}$ Recall that EFTA aimed not only to dismantle industrial tariffs between its own member states, but eventually to negotiate tariff reductions vis-à-vis the EEC as well.

${ }^{11}$ Which is when reliable GDP estimates for Wales and Northern Ireland become available.
} 


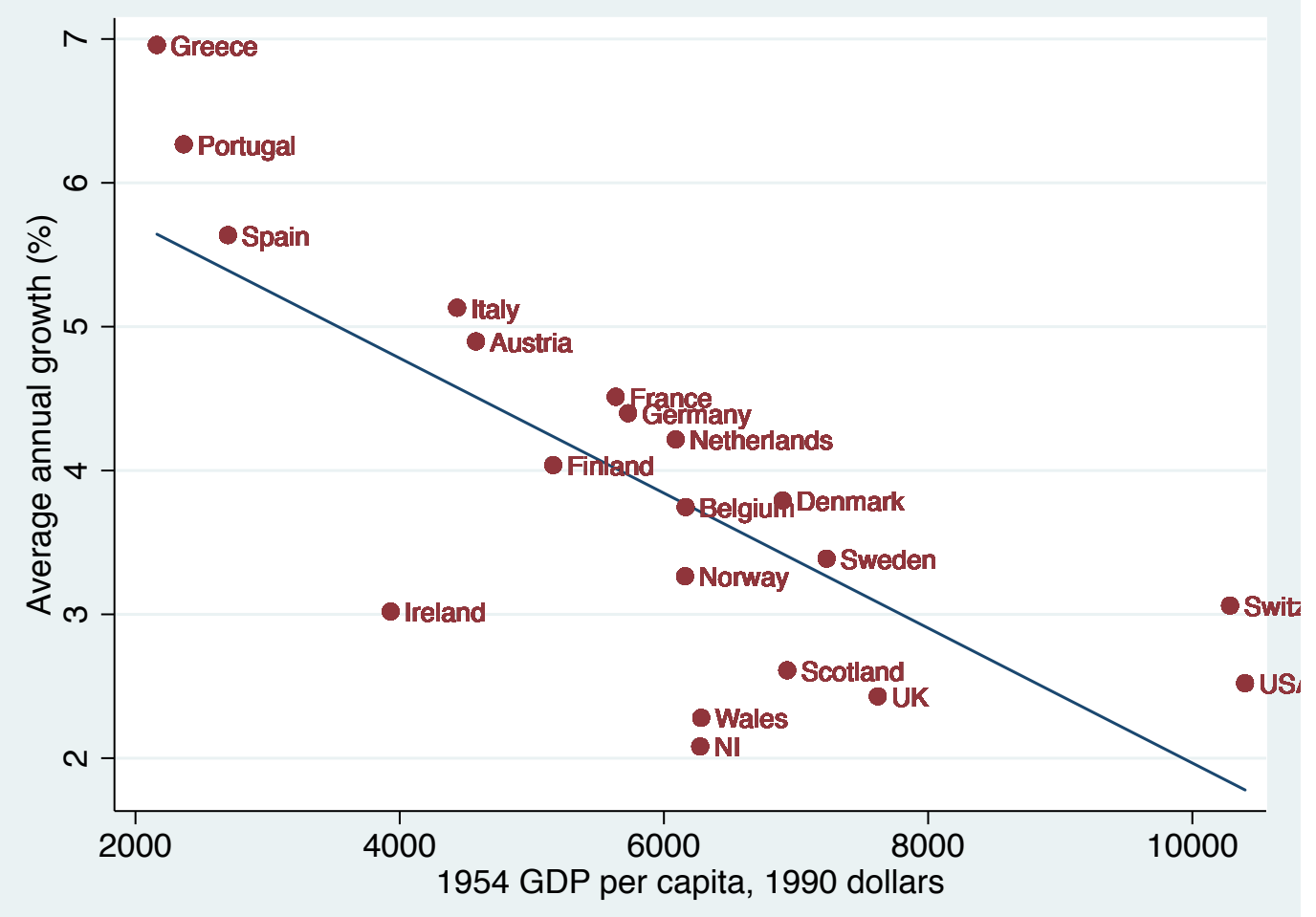

Figure 9. Initial income and subsequent growth, 1954-73

Source: as for Figure 3. Wales and Northern Ireland: data underlying Dorsett (2013), graciously provided by author. Scotland: data graciously provided by Brian Ashcroft.

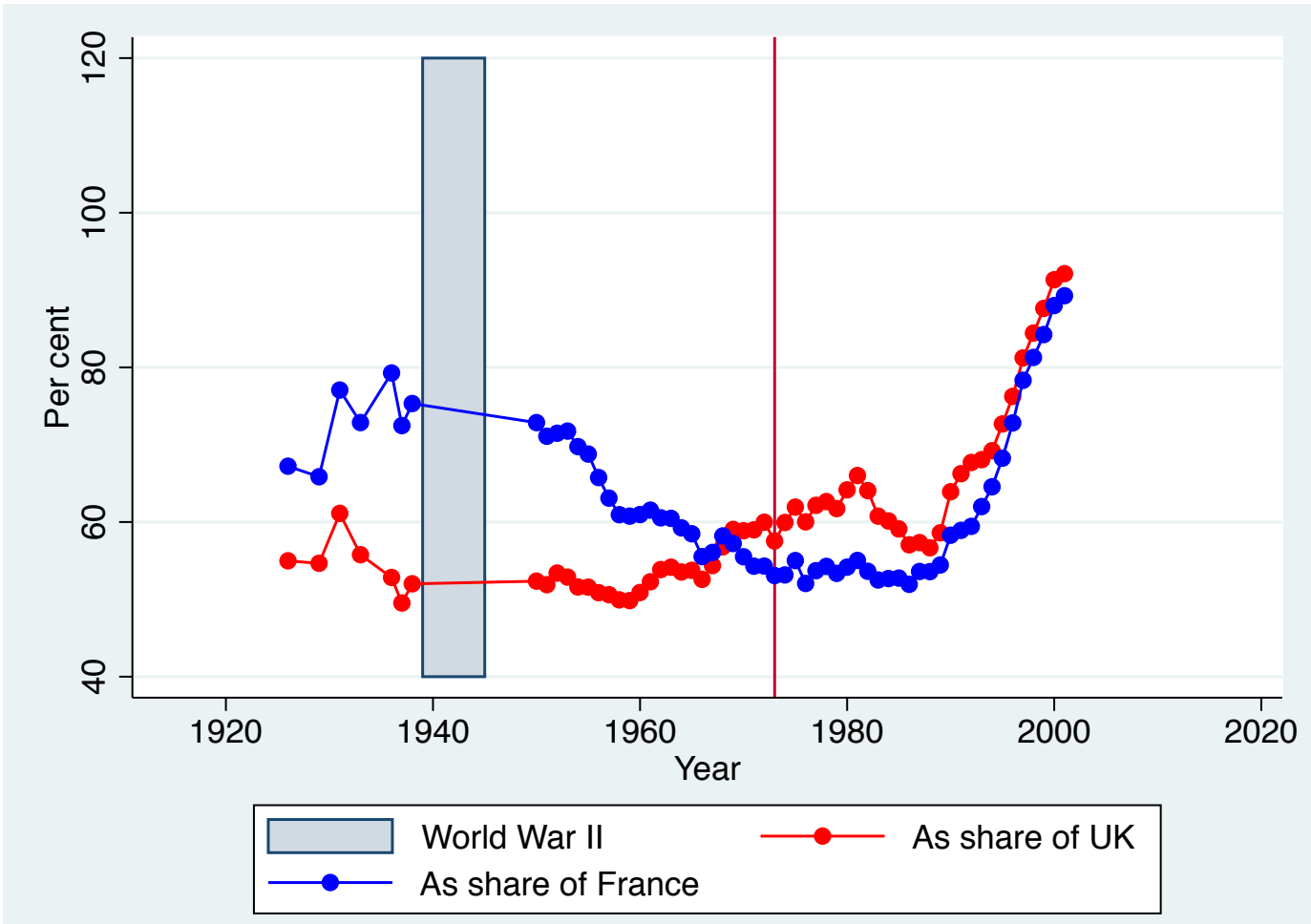

Figure 10. Irish GNP per capita as percentage of UK and French GDP per capita Source: as for Figure 3. Note: the vertical line denotes 1973. 
In consequence, while GDP per capita grew more rapidly in Ireland than in the UK during the 1960s (Figure 10), this was not sufficient to prevent Ireland falling even further behind a major continental economy like France. This would change in 1973.

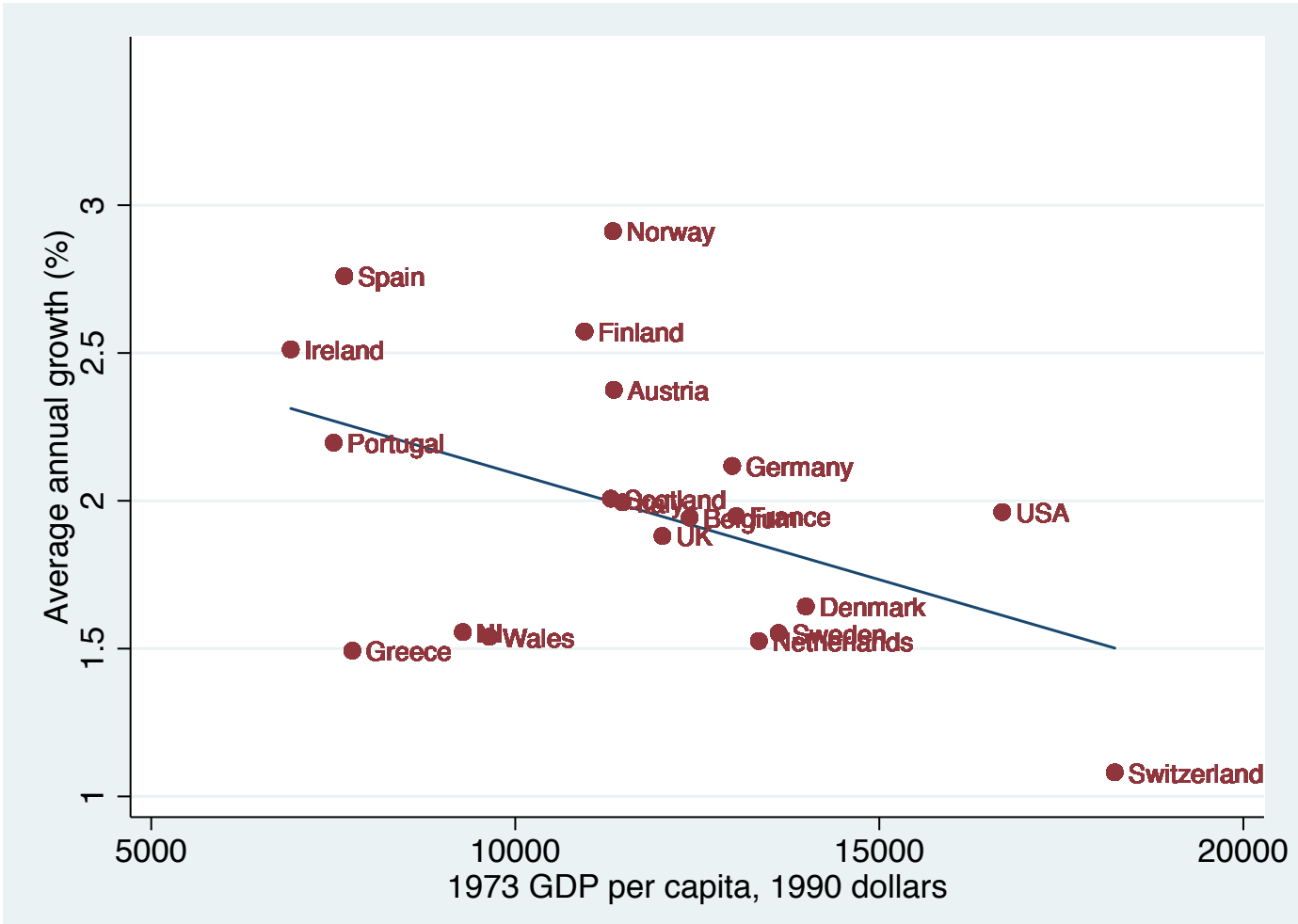

Figure 11. Initial income and subsequent growth, 1973-1990

Source: as for Figure 3.

\section{Ireland in Europe}

As Figure 10 shows, Ireland immediately stopped falling further behind France once it entered the EEC in 1973: Campos et al. (2014) estimate that membership boosted Ireland's per capita growth rate by almost 2 percentage points. Of course, many other events were shaking up the international economic landscape at this time, most obviously the oil crises of 1973 and 1979. These led to a decade or more of high unemployment, high inflation, and even higher unemployment as governments attempted to lower the inflation rate. All of these developments hurt Ireland. And yet, even before the Irish economic miracle of the 1990s, Ireland was once again growing just about as rapidly as would have been predicted within a convergence framework (Figure 11). Foreign direct investment, based on selling 
into the EEC, was the major factor improving Irish performance from 1973 onwards, although the Common Agricultural Policy clearly also helped. We would certainly have done even better had it not been for the budgetary mistakes of the late 1970s, and their inevitable consequences in the succeeding decade.

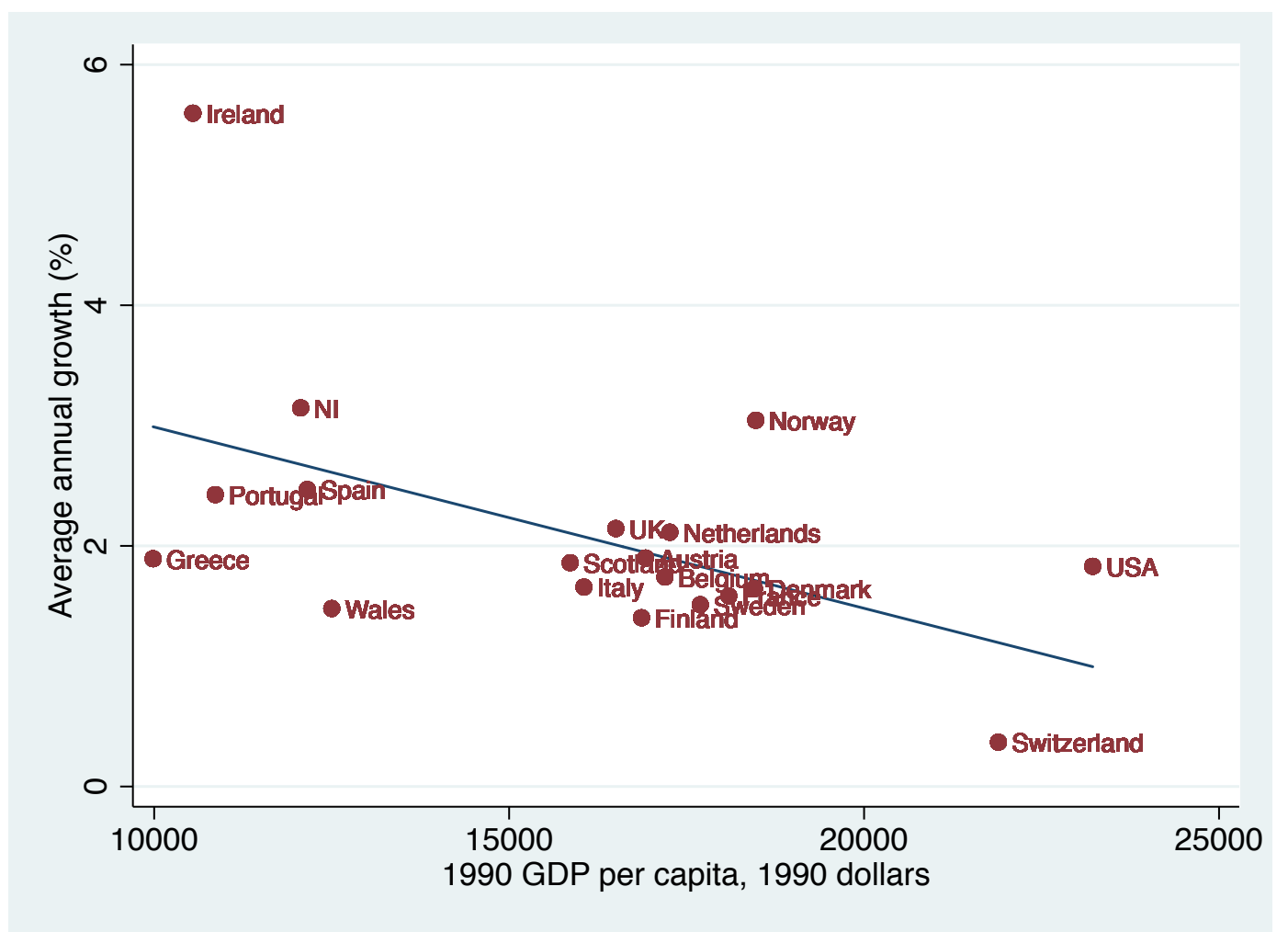

Figure 12. Initial income and subsequent growth, 1990-2001

Source: as for Figure 3.

The second major turning point in Ireland's economic fortunes was of course the short period between 1987 and 1990. During the 1990s, Ireland was, as we all know, an extraordinary over performer (Figure 12). A comparison between Ireland, on the one hand, and Northern Ireland, Scotland and Wales on the other, is informative (Figure 13). Ireland had been gaining ground on these UK regions from 1960 onwards, as we have already seen, which might represent a gradual process of convergence occurring within the British and Irish regional economy. The acceleration from 1990 onwards, however, represents something entirely different. It seems clear, not only that the European Union was fundamental in transforming the Irish economy, but that Irish independence was essential in exploiting the opportunities which the European Union afforded. As the figure suggests, 
we would never have done anywhere near as well as we in fact did, had we remained a mere region of the United Kingdom.

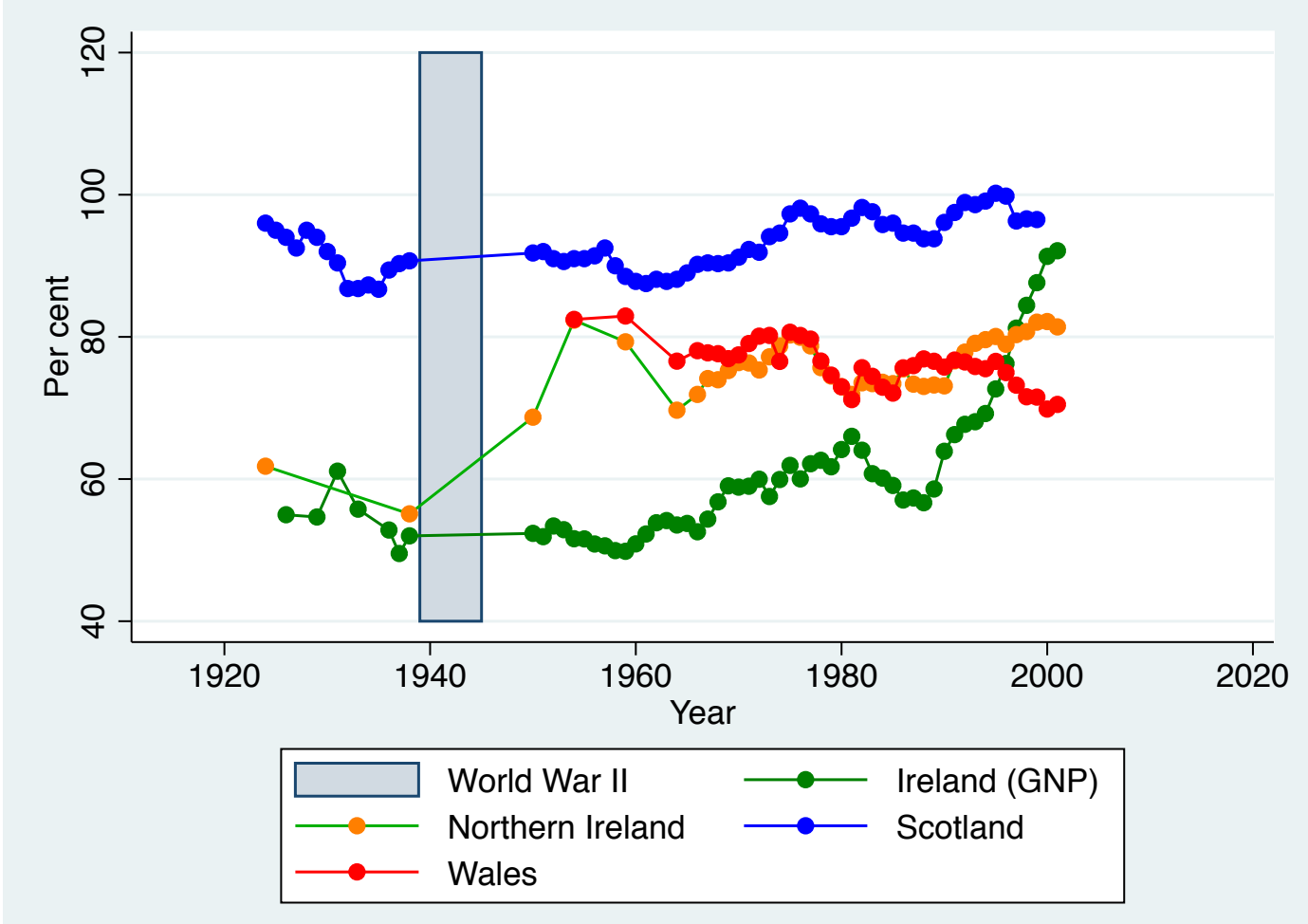

Figure 13. Incomes relative to UK, 1924-2001

Source: as for Figure 9.

Policy flexibility at a time of rapid change was essential, and that is what independence gave us. It's important to note that Ireland is not the only small European country to have performed well in the context of a globalising economy. There is a well-established political science literature that shows how other small European countries, in Scandinavia and elsewhere, have been able to respond nimbly and flexibly to changing international market conditions, in ways that larger countries have found more difficult (Katzenstein, 1985). But EU membership, and the single market programme of the late 1980s and early 1990s, were essential in allowing Ireland to finally reap the full economic rewards of its independence.

The policy mix that we adopted is well known: a low corporation tax and other incentives for inward investment, including investment in education and infrastructure. Cormac Ó Gráda and I have also argued that social partnership was important, moderating wage growth and providing a stable industrial relations environment (Ó Gráda and O'Rourke, 
2000). ${ }^{12}$ Underpinning everything was two crucial factors: our political independence, which allowed us to adopt a policy mix well suited to our own circumstances; and our membership of the European single market, without which none of this would have worked. Political independence and EU membership where never fundamentally at odds with each other in Ireland; both were required to give full effect to the other. Our independence would not have worked as well as it did without the EU; our EU membership would not have worked as well as it did without independence.

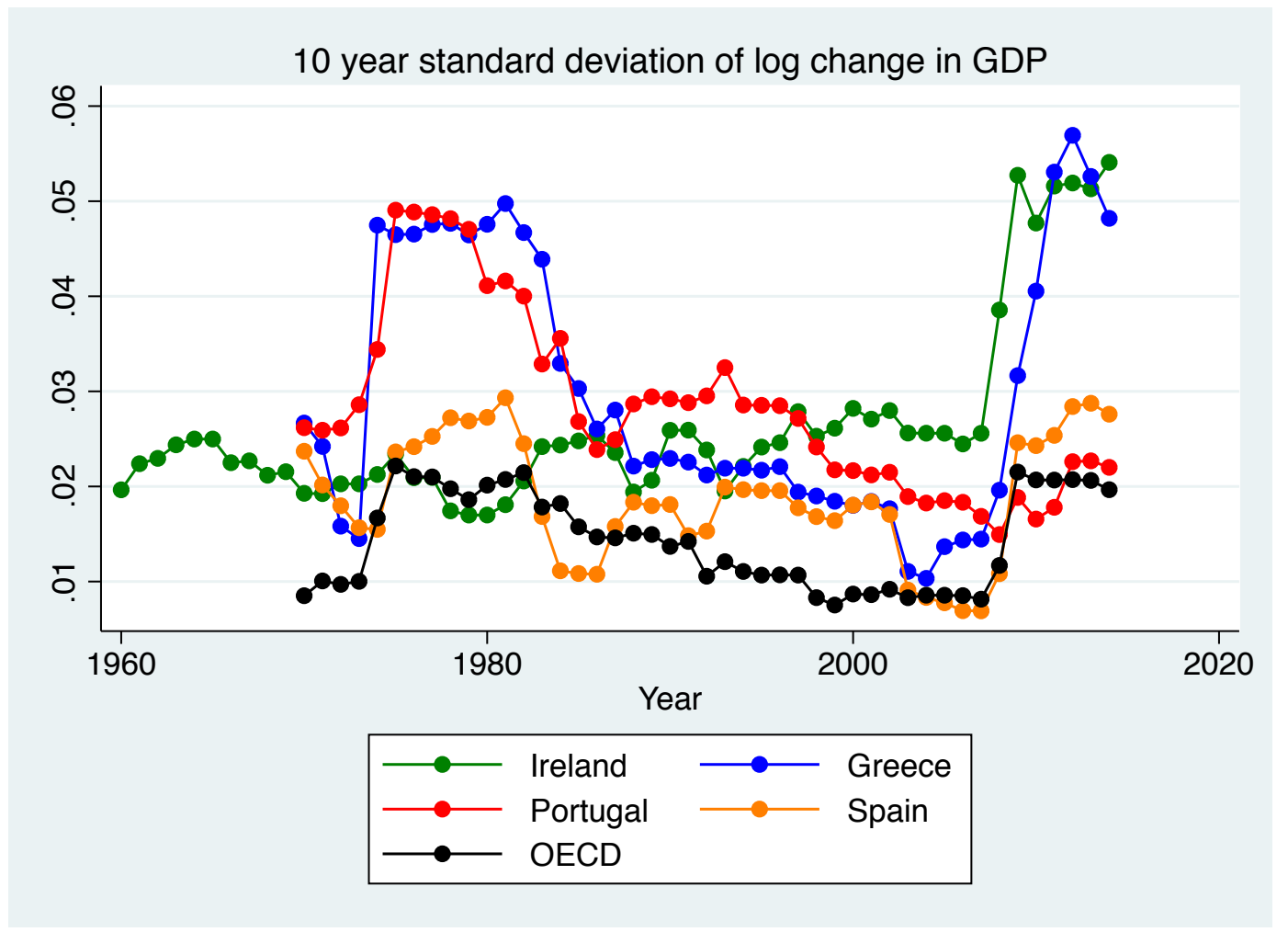

Figure 14. OECD and peripheral European GDP volatility, 1960-2014 Source: as for Figure 3.

Since 1973, and even more so since 1990, Ireland has become a hyper-globalized country whose subsequent economic history has mirrored the ebbs and flows of the global economy, in highly exaggerated fashion. The recession of the early 1980s, as inflation was squeezed out of the Western economic system; the Clinton/Greenspan IT boom of the 1990s; the credit and housing bubbles of the Great Moderation; the economic collapse of 2008 , and the subsequent recovery: Ireland experienced all of them, in spades. This

12 Just as it had done on the continent during the European Golden Age (Eichengreen, 1996). 
heightened sensitivity to international economic conditions in part reflects the country's extraordinary openness, but it also reflects an Irish tendency to spend when times are good, and to borrow when they are not. In the OECD as a whole, GDP volatility declined after the turmoil of the 1970s; in Ireland, if anything it increased - even before the extraordinary bubble and bust of the early $21^{\text {st }}$ century (Figure 14). It seems as though this volatility is to some extent a common feature of the peripheral European economies I have been comparing us to throughout this talk; but noting this does nothing to diminish the problem, and moderating this volatility needs to be a major policy priority for the country going forward.

\section{The challenges of Brexit}

The other major priority is adjusting to Brexit, and, perhaps, to the economic consequences of a Trump Presidency. Exactly what challenges Brexit will imply is unclear, and will remain so until the British government finally decides what it wants. There is no doubt but that a Hard Brexit would be damaging to Ireland. It would be an unfriendly act, not in the sense that the British would be trying to hurt Ireland -- of course they would not be -- but in the sense that the damage a Hard Brexit would cause us would be of no great concern to them either way. It was ever thus: England is a big country, and can't reasonably be expected to do anything other than to pursue its own best interest as it sees it, without taking too much account of the interests of the smaller countries on these islands. That is why in my view Irish independence was always both inevitable and desirable, but that is another matter.

Because a Hard Brexit would damage Irish interests, it's logical that we should desire that our nearest neighbours not proceed with it. But it's important that this desire not lead us to engage in wishful thinking. Once Britain has left the EU, the EU will be obliged under WTO rules to impose tariffs on imports coming from the UK. This is not something that the EU can avoid: if it were not to do this, it would be discriminating against its other trading partners, and that is illegal. The only circumstance in which the EU would be allowed to not impose tariffs on British goods is if there were a legally registered free trade agreement of one sort or another in place at the moment that Brexit occurs. And there are two major problems here. First, it is far from clear that it will be legally possible to negotiate a free trade 
agreement with the UK while it remains a member of the EU. But even if it is legally possible, which seems doubtful, there is a second, practical consideration, which is that it takes years for trade deals to be negotiated and ratified. The chances of a comprehensive deal between the EU and UK being ironed out within two years are zero.

So if we are to avoid tariff barriers, either between the Republic of Ireland and the North, or, preferably, between Ireland and Britain, we are going to need a transitional arrangement of some sort that can be easily agreed within the two-year framework, without too much substantive negotiating being involved. A detailed bespoke transitional agreement seems impossible - it will be just as difficult to negotiate as a permanent agreement, in part because transitional agreements often last a very long time. And so it will have to be an offthe-shelf arrangement - temporary membership of the European Economic Area for example, or temporary membership of the EU customs union. If the British decide that they don't want either of these options, or some other easily available alternative, on even a transitional basis, then Hard Brexit will become inevitable. And it is important to be clear that it will be British choices, and not anyone else's, that will have caused this outcome.

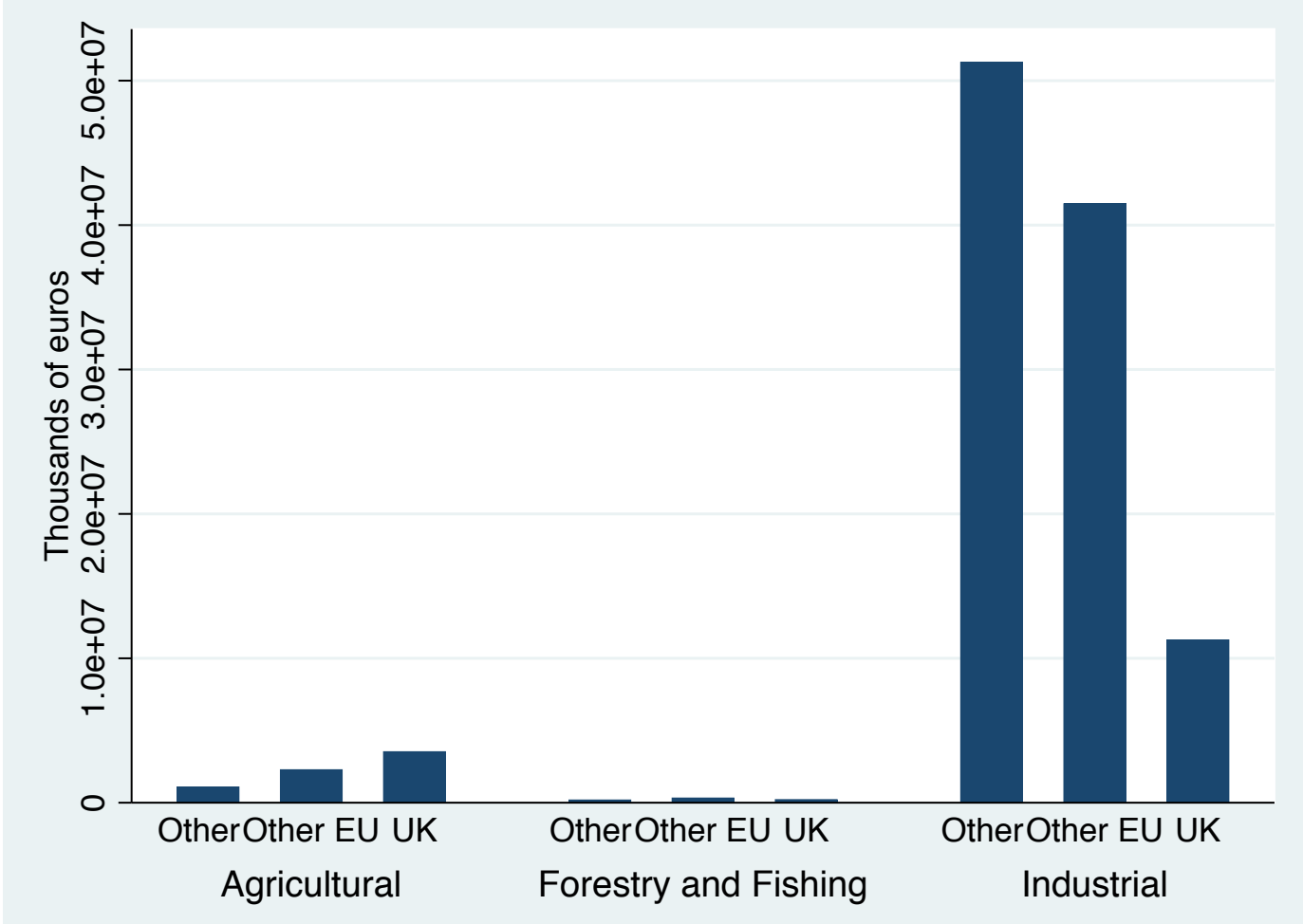

Figure 15. The destination of Irish exports, 2015 Source: CSO 
The problem for Ireland is that, although our prosperity is based on our membership of the EU single market, a comparatively high share of Irish exports still goes to Britain. It's important to be clear: other European markets are far more important to us (Figure 15). They are, as I have emphasised, the basis of our prosperity. No sane Irish politician would choose the British market over the far larger European one. But Britain is still our major agricultural market, and many of our smaller, more labour-intensive indigenous industries still sell a lot there. This matters, since food and agricultural tariffs are particularly high, and since these sectors are more employment-intensive than some of the higher-profile multinational sectors.

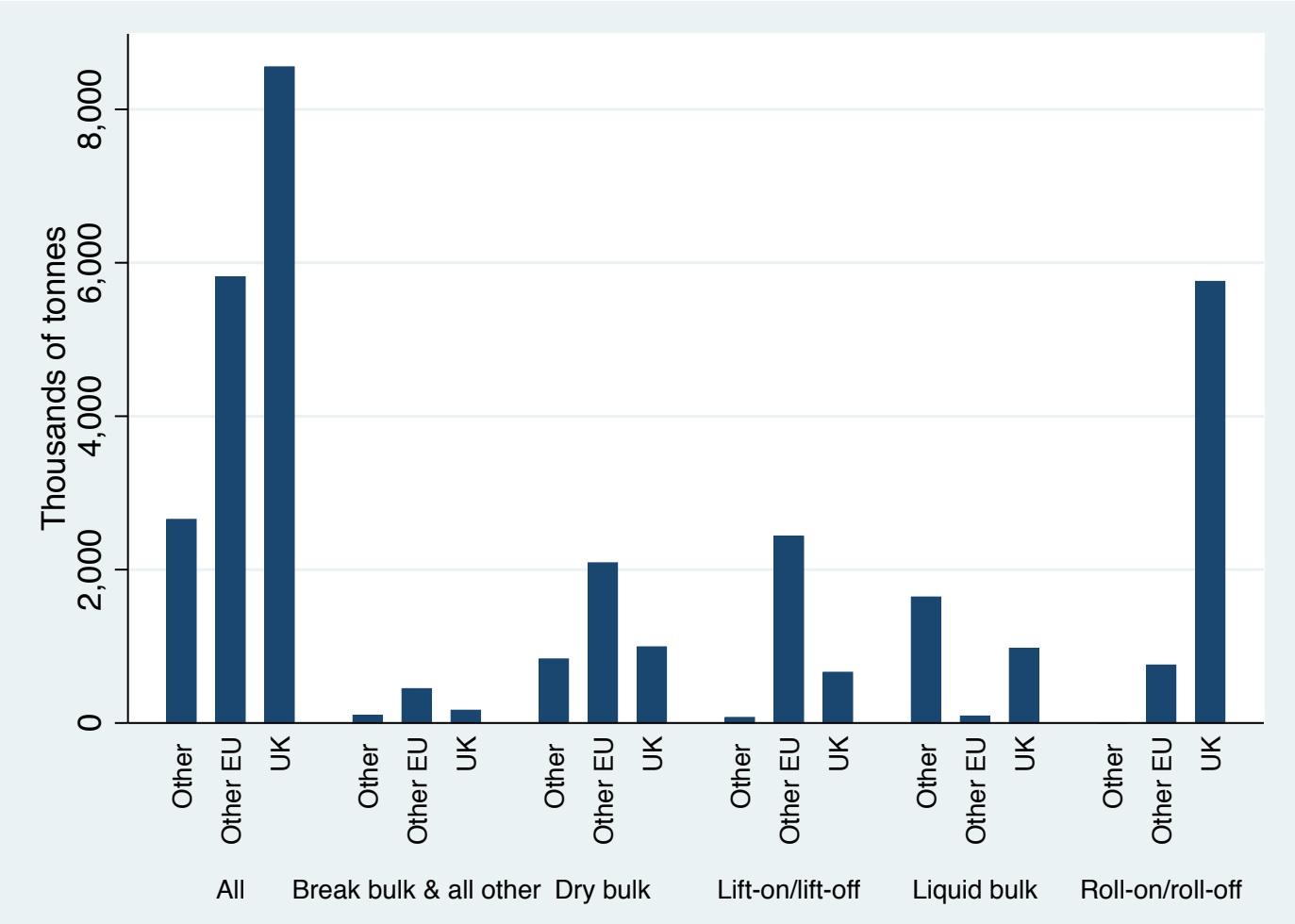

Figure 16. Merchandise trade, goods forwarded (absolute tonnage) Source: CSO

Another potential concern is the very high share of Irish merchandise exports being shipped to, and in some cases through, the United Kingdom (Figure 16). Especially worrying is the large share of roll-on roll-off traffic going to the UK; it seems likely that those smaller, labour-intensive firms exporting food and other products, who risk losing sales to the UK, are predominantly exporting their products in this fashion. To what extent might customs 
delays at Dover and Calais impose extra costs on them when they export to the Continent? We don't know yet, but it seems to me that this is also a potential concern.

What is clear is that Brexit is going to require that we adjust. How well we adjust will define our future prosperity over the course of the next couple of decades. But we're going to have to adjust anyway, probably, since the kind of hyper-globalization that we have been so good at exploiting is becoming politically unsustainable throughout the western world. We don't want to find ourselves on the wrong side of history.

We are hardly the first country to have faced this sort of external trade shock. Finland's problems in 1991, when it found itself having to cope with the consequences of the breakup of the Soviet Union, with whom a huge share of its trade had previously been conducted, were probably more serious than those that we are likely to face; its adjustment was exemplary. Late $19^{\text {th }}$ century Denmark found itself facing higher tariff barriers in its traditional German market after 1879 , as well as prohibitions on live cattle exports which lasted several years. It also successfully adjusted, switching into dairying and other activities targeting the British, rather than the German, market. Ireland itself had to adjust during the 1960s, as the manufacturing industries that had been built up during the protectionist era became exposed to international competition. We will have to do so again.

It is time to conclude. I have argued that Irish prosperity in recent decades has depended both on our membership of the European Union, and on our political independence which allowed us to make the most of that membership, by giving us the freedom to make policy choices that were suited to our own circumstances. Much the same has been true for several other small European countries: once again, our own national story is part of a larger picture. We are not so different as we sometimes think we are.

Of course we have made mistakes - it would have been odd had we not done so, especially in the context of the $20^{\text {th }}$ century. But our mistakes were not particularly unusual, or especially egregious; and they were eventually remedied. And isn't it the case, whether we are dealing with individual human beings, or with entire nations, that having the freedom to 
make your own mistakes, and learn from them, rather than being permanently subjected to the consequences of other peoples' mistakes, is what freedom is all about? 


\section{References}

Adler-Olsen, J. (2014). Guilt. London: Penguin Books.

Arndt, H. W. (1976). Non-Traded Goods and the Balance of Payments:The Australian Contribution. Economic Record 52, 104-107.

Barry, F., Barry, L. and Menton, A. (2016). Tariff-jumping foreign direct investment in protectionist era Ireland. The Economic History Review 69, 1285-1308.

Barry, F. and Bradley, J. (1997). FDI and Trade: The Irish Host-Country Experience. The Economic Journal 107, 1798-1811.

Barry, F. and O'Mahony, C. (2016). Costello, Lemass and the Politics of the New Foreign Investment Regime of the 1950s. Mimeo.

Broadberry, S. and Klein, A. (2012). Aggregate and per capita GDP in Europe, 1870-2000: continental, regional and national data with changing boundaries. Scandinavian Economic History Review 60, 79-107.

Campos, N. F., Coricelli, F. and Moretti, L. (2014). Economic Growth and Political Integration: Estimating the Benefits from Membership in the European Union Using the Synthetic Counterfactuals Method. Centre for Economic Policy Research Discussion Paper 9968.

Clemens, M. and Williamson, J. (2004). Why did the Tariff-Growth Correlation Change after 1950? Journal of Economic Growth 9, 5-46.

Costa, L. F., Lains, P. and Miranda, S. M. (2016). An economic history of Portugal, 1143-2010. Cambridge: Cambridge University Press,.

Daly, M. E. (1984). An Irish-Ireland for Business?: The Control of Manufactures Acts, 1932 and 1934. Irish Historical Studies 24, 246-272.

Daly, M. E. (1992). Industrial development and Irish national identity, 1922-1939. New York: Syracuse University Press.

das Neves, J. L. C. (1996). Portuguese postwar growth: a global approach. In Economic Growth in Europe since 1945:(Eds, Crafts, N. and Toniolo, G.). Cambridge: Cambridge University Press, 329-354.

de la Escosura, L. P. and Sanz, J. C. (1996). Growth and macroeconomic performance in Spain, 1939-93. In Economic Growth in Europe since 1945:(Eds, Crafts, N. and Toniolo, G.). Cambridge: Cambridge University Press, 355-387.

Dorsett, R. (2013). The effect of the Troubles on GDP in Northern Ireland. European Journal of Political Economy 29, 119-133.

Eichengreen, B. (1996). Institutions and economic growth: Europe after World War II. In Economic Growth in Europe since 1945:(Eds, Crafts, N. and Toniolo, G.). Cambridge: Cambridge University Press, 38-72.

Eichengreen, B. and Irwin, D. A. (2010). The Slide to Protectionism in the Great Depression: Who Succumbed and Why? The Journal of Economic History 70, 871-897.

Ferreira da Silva, A. I. (2016). Multinationals and foreign direct investment: The Portuguese experience (1900-2010). Journal of Evolutionary Studies in Business 2, 40-68.

Freris, A. (1986). The Greek economy in the twentieth century. London: Croom Helm.

Guinnane, T. (1997). The vanishing Irish : households, migration, and the rural economy in Ireland, 1850-1914. Princeton, N.J.: Princeton University Press.

Hatton, T. J. and Williamson, J. G. (1994). What Drove the Mass Migrations from Europe in the Late Nineteenth Century? Population and Development Review 20, 533-559.

Hatton, T. J. and Williamson, J. G. (1998). The age of mass migration : causes and economic impact. New York ; Oxford: Oxford University Press. 
Hjerppe, R. (2004). The Significance of Foreign Direct Investment in a Small Industrializing Economy: The Case of Finland in the Interwar Period. Business and Economic History On-Line 1, 1-21.

Jones, G. (2013). Entrepreneurship and multinationals : global business and the making of the modern world. Cheltenham: Edward Elgar.

Katzenstein, P. J. (1985). Small states in world markets : industrial policy in Europe. Ithaca: Cornell University Press.

Kopsidis, M. and Ivanov, M. (2017). Industrialization and De-industrialization in Southeast Europe, 1870-2010. In The Spread of Modern Industry to the Periphery since 1871(Eds, O'Rourke, K. H. and Williamson, J. G.). Oxford: Oxford University Press, 91114.

League of Nations (1943). Quantitative trade controls : their causes and nature. Geneva: League of Nations.

Lehmann, S. H. and O'Rourke, K. H. (2010). The Structure of Protection and Growth in the Late Nineteenth Century. Review of Economics and Statistics 93, 606-616.

Lieberman, S. (2006). The contemporary Spanish economy : a historical perspective. London: Routledge.

Neary, J. P. and Ó Gráda, C. (1991). Protection, economic war and structural change: the 1930s in Ireland. Irish Historical Studies 27, 250-266.

Ó Gráda, C. (1997). A rocky road : the Irish economy since the 1920s. Manchester New York: Manchester University Press.

Ó Gráda, C. and O'Rourke, K. (1996). Irish economic growth, 1945-88. In Economic Growth in Europe since 1945:(Eds, Crafts, N. and Toniolo, G.). Cambridge: Cambridge University Press, 388-426.

Ó Gráda, C. and O'Rourke, K. H. (2000). Living standards and growth. In The Economy of Ireland: Policy and Performance of a European Region(Ed, O'Hagan, J.). Dublin: Gill and Macmillan, 178-204.

O'Rourke, K. (1991). Burn Everything British but Their Coal: The Anglo-Irish Economic War of the 1930s. The Journal of Economic History 51, 357-366.

O'Rourke, K. H. and Williamson, J. G. (1999). Globalization and history : the evolution of a nineteenth-century Atlantic economy. Cambridge, Mass.: MIT Press.

Paavonen, T. (2004). Finland and the question of West European economic integration, 1947-1961. Scandinavian Economic History Review 52, 85-109.

Whittlesey, C. R. (1937). Import Quotas in the United States. The Quarterly Journal of Economics 52, 37-65. 
UNIVERSITY OF OXFORD DISCUSSION PAPERS IN ECONOMIC AND SOCIAL HISTORY are edited by

Rui Esteves (Brasenose College, Oxford, OX1 4AJ) Gabriel Geisler Mesevage (Brasenose College, Oxford, OX1 4AJ) 